\title{
An overview of terry towel industry in Bangladesh with swot analysis
}

\author{
Mohammad Abu Bakar Siddiquee*, Abul Kashem Mohammad Ayatullah Hosne Asif, \\ Mahbubur Rahman
}

Faculty of Engineering, Department of Textile Engineering, Mawlana Bhashani Science and Technology University, Tangail, Bangladesh

\section{Email address:}

bakarsiddiquee_69@yahoo.com (M. A. B. Siddiquee), asifte08@gmail.com (A. K. M. A. H. Asif),

mahbub.mbstu@gmail.com (M. Rahman)

\section{To cite this article:}

Mohammad Abu Bakar Siddiquee, Abul Kashem Mohammad Ayatullah Hosne Asif, Mahbubur Rahman. An Overview of Terry Towel Industry in Bangladesh with Swot Analysis. International Journal of Business and Economics Research. Vol. 3, No. 1, 2014, pp. $37-41$. doi: 10.11648/j.ijber.20140301.15

\begin{abstract}
The aim of this study was to increase the knowledge of terry products scope, products demand and supply, buyer or market of products, product range, export volume, trend and reveals other opportunities, strength, threat etc of this sector. Terry towel is one of the rapid growing and exigent sub sector of the textile sector of Bangladesh. Bath robes, hand towel, kitchen towel etc. are the products from terry in one word. Demands of these products are increasing very fast globally and also significantly day by day in the local market. Consumers pay on an average $\$ 7$ for bath towel and their households in America. In last decades, the importance of this sector has been increased enormously with the incremental global demand. As Bangladesh is one of the major terry products exporting country among the terry manufacturing countries of the world, the market analysis and SWOT analysis of terry products is the demand of time for the terry manufacturer of our country. Bangladesh is the number one choice of the importers for higher quality with low price of terry product specially terry towel.
\end{abstract}

Keywords: Terry Towel, SWOT (Strength, Weakness, Opportunity, Threat), Golf Towel, Beach Towel, Bath Towel

\section{Introduction}

There is no denying of the fact that, we are living in an age of modern science and technology. Modern science and technology is developing day by day. Bangladesh terry towel industry is $100 \%$ exports oriented industries producing and exporting assorted quality of towels and allied products. This sector started its maiden venture with only one industry in 1984. There having a good demand in the world market. This infant industry developed very rapidly and the numbers of towel related items are developing day by day at present. In financial year 20122013 (July-May) the export was US \$75.42 million and US $\$ 88.13$ million has been projected for the financial year 2013-2014. Terry Towel is the highest value addition item among other exportable textile products. This sector has directly employed over 48 thousand men and women. It is needless to say that, that many interested buyers from home and abroad will be able to contact terry towel manufactures and exporters directly through the website. It is a potential sector of Bangladesh's economy and manufacturers are endeavoring hard to attain the best possible success in the sector by exploring more revenues for expansion of terry towel export. Terry fabrics basically belong to the group of pile fabrics, in which an additional yarn is inserted in such a manner that forms loop, called as pile, to give a distinct appearance. These fabrics can be produced either by weaving or by knitting but woven terry fabric, which is the first method invented, still has major share. This is because the quality of knitted terry fabric is not equal to that of woven terry fabric. In terry fabric manufacturing, two sheets of warp threads run at once, of which, one is kept under normal tension and other is kept under loose tension. Generally, Bangladesh produces terry towel products, which are low-end, average-quality towels mostly worth \$3-7 per kilogram. But, as per the industry insiders, the new entrants have targeted the high-end segment of the market that costs \$8-13 per kilogram. Towel doesn't need accessories like readymade garments. Cheap labor is the additional advantage. The trade in textile and apparel has become more and more liberalized over the years especially. The trade liberalization has yielded globalization effect on 
the global textile and apparel market. This Trade liberalization accompanied a globalization movement for the textile industry. The Bangladesh textile industry has grown over the years and the terry towel industry in Bangladesh is now one of the largest towel producers in the world. Terry or Turkish towels were originated in Turkey, wherein these fabrics were woven in handlooms. In the middle of 19th century this technique of weaving towels was further refined in the European countries and took a shape of power driven looms.

\subsection{Objectives of the Study}

The overall aim of this study was to investigate the performance improvement through SWOT analysis in commercial perspective in Bangladesh. The specific objectives for the research are: to characterize the extent of determining products scope, demand which have used analyzing and to determine the significant effect of demand, supply mentioning overall performance.

\subsection{Significance of the Study}

The information from this study will be crucial on the Analysis of strength and weakness of terry towel industry. All home textile and processing based industries will benefit from these insights with respect to this study in their policy formulation and implementation in their strategic plan with respect to the continuous improvement principle of SWOT analysis in order to create competitive advantage and optimize on resource use in order to serve their clients better and improve their performance. The study findings will also be of great help to researchers/Academicians as it will identify gaps which are necessary for further research in areas related to textile industrial management along with home textiles. Other Organizations will also use the findings in policy formulation and implementation with respect the continuous improvement principle of SWOT analysis.

\subsection{Scope and Limitation of the Study}

This study covered banks located within Gazipur industrial town in Dhaka, Bangladesh. The study largely focused on performance improvement through supply, demand in Bangladesh. It mainly involved management level staff in the banks operating in Gazipur industrial zone being the policy makers that give organizational direction. Export promotion Bureau of Bangladesh not listed on the export listing of 14th October 2013 was not covered by the study.

\section{Overview of Bangladesh Terry Towel Sector}

As Bangladesh is one of the worlds's most important terry towel producers by volume and value so the table is shown below total export in last decade.

Table 1. Total Export in Different Fiscal Year.

\begin{tabular}{cccc}
\hline Year & $\begin{array}{c}\text { Total Export } \\
\text { (Million US\$) }\end{array}$ & $\begin{array}{c}\text { (\%) Share of } \\
\text { Total Export }\end{array}$ & $\begin{array}{c}\text { (\%)Annual } \\
\text { Change }\end{array}$ \\
\hline $2002-03$ & 48.05 & 0.74 & +4.95 \\
$2003-04$ & 50.43 & 0.84 & +12.18 \\
$2004-05$ & 56.98 & 0.86 & +20.74 \\
$2005-06$ & 68.31 & 0.90 & -5.15 \\
$2006-07$ & 64.79 & 0.75 & +23.70 \\
$2007-08$ & 80.15 & 0.76 & +35.16 \\
$2008-09$ & 103.77 & 0.85 & +37.53 \\
$2009-10$ & 112.88 & 0.90 & +21.11 \\
$2010-11$ & 132.57 & 0.96 & +27.54 \\
$2011-12$ & 149.08 & 0.96 & +27.65 \\
$2012-13$ & 159.43 & 0.89 & +28.24 \\
\hline
\end{tabular}

(Source: Export Promotion Bureau)

The table shows the total export comparison between 2012-13 over 2009-10. The table above show that the terry towel sector is growing in a good pace and consistently. Though the export value could have been higher it is maintaining a sustainable growing trend throughout the decade. No major deflection indicates a descent future as well.

\subsection{Range of Products}

Bangladesh is largely produces different types of terry towel for export among those face towel, hand towel, plain/terry kitchen towel, stripped bath towel, terry towel; assorted color bath towel, dyed terry bath towel, golf towel, Bath robe towel etc are remarkable. Beach towels are usually in bright colors. They have interesting patterns printed or woven into them, most of them being cool, fun and youthful. They also come in bright and colorful stripes. Kids' beach towels come with printed or woven pictures of their favorite Disney characters and super heroes.

The main purpose of a bath towel is for drying one's body after a bath or shower. They are generally woven with a soft and absorbent loop or pile and are thus used to wick the water away from the body. In accordance to their specific use and size Bath towels are divided into Wash Cloth Towel, Hand Towel, Standard Bath Towels, and Bath Sheets.

Table 2. The top ten Terry Towel exporters to the United States for the 2012 and 2013 on valued by million US\$.

\begin{tabular}{|c|c|c|c|c|c|c|}
\hline Country & 2013 & 2012 & $\%$ of change & 1st 3 months of 2012 & 1st 3 months of 2013 & $\%$ of change \\
\hline World & 1389.763 & 1324.457 & -4.936 & 374.253 & 386.971 & 3.29 \\
\hline India & 572.719 & 562.954 & -1.73 & 114.966 & 121.639 & 5.49 \\
\hline China & 488.488 & 482.744 & -1.2 & 113.196 & 120.947 & 6.41 \\
\hline Brazil & 114.368 & 101.265 & -12.94 & 37.768 & 36.764 & -2.73 \\
\hline Turkey & 87.760 & 60.998 & -43.87 & 28.210 & 30.182 & 6.53 \\
\hline Bangladesh & 53.244 & 55.916 & 4.78 & 29.430 & 28.114 & -4.68 \\
\hline Egypt & 42.217 & 37.960 & -11.21 & 28.657 & 26.679 & -7.41 \\
\hline Columbia & 30.967 & 22.620 & -36.90 & 22.026 & 22.649 & 2.75 \\
\hline
\end{tabular}




\subsection{Destinations of Main Export}

Leading export destinations of Bangladeshi terry towel are European Union countries and USA Bangladesh is also exporting to some Asian countries. In the year 2009 Bangladesh positioned 6th among top towel exporter to the USA and 5th in the year 2008. Among the EU countries- UK, France, Germany, Italy, Greece Spain, Sweden, Poland, Finland, Netherlands are importing significant amount of terry towel. Total Export Volume to EU market in 2012-13 fiscal years was US\$ 38186 thousands. Then other markets for terry towel like NorthSouth American countries (Canada, Mexico, Colombia, Brazil, Chile etc.) imported US\$ 18792 thousand in 201213; Asia (India, Russia, Korea, Malaysia , Japan etc.) imported US\$ 5211 thousand in 2012-13; Middle East (Lebanon, UAE, Turkey, Iran, Egypt etc.) imported US\$ 1865 thousand in 2012-13.

\subsection{An overview of Global Market}

It is needless to say that, major Terry towel exporting countries to US market are India, China, Pakistan, Brazil, Turkey, Thailand, Israel, Egypt and Vietnam.

Table 3. Bath Towel Exporters to the United States (\$ millions).

\begin{tabular}{ll}
\hline Company name & Country \\
\hline Abhishek Industries & Mumbai, India \\
Welspun & Mumbai, India \\
Karsten, Blumeneau & Brazil \\
Loftex & Jinzhou, China \\
Sunvim & Qingdao, China \\
\hline
\end{tabular}

\section{SWOT Analysis}

A SWOT analysis is a structured planning method used for evaluating the strengths, weaknesses, opportunities, and threats involved in a project or in a business venture. A SWOT analysis can be carried out for a product, place, industry or person. It involves specifying the objective of the business venture or project and identifying the internal and external factors that are favorable and unfavorable to achieving that objective. Bangladesh terry towel industries SWOT analysis is given here. Strength and weakness of the terry towel industry has been illustrated and some alternatives and remedies have been suggested so as to make the terry towel industry competitive and efficient against our biggest challengers Vietnam, Pakistan, India and China.

\subsection{Strength}

Researchers found that the cost of labor is one of the key factors for Bangladesh's success - as the average wage per hour of garment factory workers in Bangladesh is only 40 US cents. Whereas the per hour wage is $\$ 1.66$ in China, 56 cents in Pakistan, 51 cents in India, 44 cents in Indonesia, 36 cents Vietnam and higher than this in Europe. The industrial people pointed out that customs dealings and terminal handling have improved here considerably in recent times. Growing number of yarn manufacturing units, the World Bank pointed out that there has been satisfactory growth in backward linkage textile industries here and another strength is that the GSP facility up to 2015 to the European Union countries as well. The main fact is that, due to the manpower engaged to carry out the day to day business are all highly skilled, purely professional, vastly experienced. The exclusive combination of organized managerial and technical with government support.

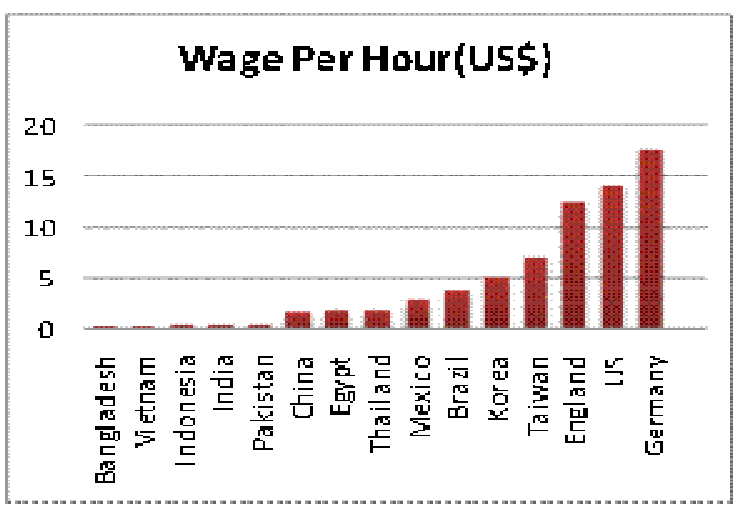

Fig 1. Wage per hour chart of garments factory workers around the world (Source: Bangladesh Textile Today).

\subsection{Weakness}

Lower cost competitiveness has hampered ability to compete with lower cost global players. Labor force in Bangladesh has a much lower productivity as compared to competing countries like China, India, and Sri Lanka etc. Cost like indirect taxes and interest are relatively high. Bangladesh has a history of labor problems. Absence of research and development $(R \& D)$ in the sector is a very big issue. Researchers from the World Bank piercing out that Bangladesh's weakness were lack of good designers and related technology. There is Shortage of skilled workers and worker's unrest, mid-level management people, was pointed out as another drawback. Inefficient infrastructure, lack of industrial expertise, outdated social standards and unavailability of raw materials were also mentioned as the major disadvantages of Bangladesh's terry industry. Technology obsolescence has resulted in the need for significant technology investments to achieve world class quality golf towel and terry towel as well. The financial problems faced by most textile mills in the state. On the other hand Bangladesh does not produce the basic raw materials (only a negligible quantity of cotton but no manufactured fiber) and as such has to depend totally on sensitive global market which is sometimes resulting in insufficient investments in technology so that inadequate backward linkage, lead-time happens to be long, nearly 3 months. Bank interest rate is still high enough, particularly 
of private sector bank, for investment of export oriented high value project. Still Bangladesh is now the world's 6th largest terry exporting country, the entrepreneurs here need to invest in new technology to improve productivity and to reinforce relationships with buyers.

\subsection{Opportunities}

Due to global consumption is increasing everyday and Bangladesh has some core competency which cannot be achievable by the competing countries, the country should have been acquiring a lion share of the global market. Bangladesh could have achieved such a price competency which would be impossible for others with the help of further increase of productivity, quality and design support. Bangladesh's towel manufacturing sector saw investments of more than Tk 1,000 crore in the last three years, with new entrants coming in to export high-quality products. A number of factories [towel] have come up with big investments. These factories produce high-end items. Shabab Fabrics invested around Tk 250 crore, particularly with the view to export its superior-quality terry towel products. The company has recently installed a production line that can produce 28 tons of towel products a day. Noman Group, a famous readymade garment manufacturer, is another one of the newcomers, who invested around Tk 150 crore for a towel factory. Meanwhile, ACS Textile has invested more than $\mathrm{Tk} 100$ crore to produce high-end terry towels. Polytex and Bismillah Towel, too, undertook further investments to expand their production capacity. Towel manufacturing in Bangladesh, until recently, has been the domain of Pakistani producers, with the first Bangladeshi-owned towel factory being set up in Chittagong in 1984. Presently, around 100 factories, mostly by Bangladeshis, are manufacturing and exporting towels, with towel exports fetching \$140 million in fiscal 2013-14.

As far as we are concerned good signs are floating while we see textile education and research is spreading where Bangladesh, as a proven experienced terry manufacturer, can expand share in the existing market (USA, Australia, EU, Canada etc.) and can also explore opportunity in Japan $\&$ CIS countries. In the future, Bangladesh has a scope to target huge populated country like China and India- where demand as well as cost of manufacturing will be wider. The government gives 5 percent incentive for towel exports to traditional markets such as Europe, Canada and the US, and 10 percent for the non-traditional markets.

\subsection{Threats}

It goes without saying that, competition is not likely to remain just in the export space; the industry is likely to face competition from cheaper imports as well. It can be as big as readymade garments. But a few exporters are damaging the potential in the international markets. Some exporters quoted the price of their low-end products as high as $\$ 12.5$ per kilogram -- for the purpose of securing government incentives. But these vested people offer $\$ 3$ per kilogram to foreign buyers who visit Bangladesh instead of the minimum $\$ 3.5$ per kilogram, he added. "Foreign buyers get puzzled to see a big difference in price between the local exporters. But what is heartening for the exporters is that the central bank and the Anti-Corruption Commission are looking into the issue of incentive misuse by certain firms, added the industry insiders. This consequence likely to affects the domestic industry and may lead to increased consolidation. Ecological and social awareness is likely to result in increased pressure on the industry to follow the international labor and environment laws; this has resulted in increased pressure on companies to limit sourcing from countries/companies known to have such practices as well. Bangladeshi industry needs to prepare for the fall out of such issues by improving its working practices. Inter regional trade blocs pay a significant role in the global terry towel industry with countries enjoying concessional tariffs by virtues of being member of such blocs/alliances. The largest threat to the textile industry is present gas crisis at every region of our country. The sudden price hike of cotton and yarn in the domestic market may push Bangladesh to a very awkward situation to devastate the business. The type of labor and political anarchies of the recent days if prevails in the future, Bangladesh may lose the business in the way Sri Lanka has lost. Growing transnational terrorism, or its false/amplified propaganda, is also a big threat. As a result no new terry industry has permitted for erection from the government.

\section{Conclusion}

At last, it is needless to say that, Bangladesh is a global competitor in towel production with increasing exports. It is really important to remind that Bangladesh's exports have increased on both value and volume bases despite its price per SME being substantially lower than the world average. Bangladesh is a value-added leader in towels. Though Bangladesh has not a strong textile and apparel industry structure which provides a competitive advantage in the global market because of some infrastructure. Bangladesh is well positioned to continue to compete in the global area and be a major supplier of towels. To sustain its place and to enhance it, Bangladesh can develop this sector as a wide export earning sector to contribute to our national economy by involving or producing Textile experts in this sector. Existing manpower should undergo massive and integrated training for skill and design development.

\section{Acknowledgements}

The authors would like to thank A.S.M. Tareq Amin, C.E.O. of Bangladesh Textile Today and S.M. Mahbubor Rahman, Director General of Export Promotion Bureau Bangladesh for their good support, help and coordination at all points during our data collection. 


\section{References}

[1] The Technology of Terry Towel Production. Journal of Textile Trade and Apparel, Technology and Management, Volume 4, Issue 4. 2005

[2] "Export Promotion Bureau” Monthly Export Datasheet.

[3] Editor, "Bangladesh: Terry towel makers demand 15pc cash incentive." The Daily Star, (May 1, 2009)

[4] Major Shippers Report Category 363 Cotton Terry/Other

Pile Towels.

http://otexa.ita.doc.gov/scripts/tqads2.exe/catdata

[5] Statistical Report Bangladesh: Export Promotion Bureau, (2002-03, 2003-04, 2004-05, 2005-06, 2006-07, 2007-08, 2008-09, 2009-10, 2010-2011, 2011-12, 2012-2013). Dhaka.

[6] "Turkish towel's Place in the Global" Market Journal of Textile and Apparel, Technology and Management Volume 5, Issue 4 (Fall 2007).

[7] US Current industrial records- bed and bath furnishing. U.S. Department of Commerce, January 08, 2005. 